\begin{tabular}{c} 
AFRICAN \\
EAST-ASIAN \\
AFFAIRS \\
\hline THE CHINAMONITOR
\end{tabular}

\title{
Grassroots Perceptions of China in Namibia: Effects on Domestic Politics and Foreign Policy
}

By Nelago Amadhila* Trainee Political Risk Analyst, Political Analysis South Africa

The dramatic expansion of Sino-Namibian relations in the last decade has led to the formation of varying perceptions of China in Namibia. Perceptions are being formed at different levels of society. Grassroots perceptions differ greatly from perceptions being formed at the top and this increasingly has an effect on domestic Namibian politics and, as such, Sino-Namibian relations. It is therefore essential to determine the importance of grassroots perceptions on China in Namibian politics and the effects of these grassroots views on Foreign Policy towards China. This paper looks at the non-official relations between Namibia and China. Non-official views are based on interviews conducted between March and April 2011. The basis for this article was a survey with $100^{1}$ respondents various social and economic backgrounds.

\section{Official Sino-Namibian Political Relations}

China's political presence is mostly defined within its official state-to-

\footnotetext{
* The author graduated from Rhodes University in 2011 with a Master of Arts in Political and International Studies. She also holds an Honours degree in Historical Studies and a Bachelors degree in English Literature and Historical Studies from the University of Cape Town. She currently works at Political Analysis South Africa Ltd as a Trainee Political Risk Analyst.
} 
state relations with the Namibian government. China and Namibia regard each other to be friends, sharing a new type of close partnership (Embassy of the People's Republic of China in Namibia; 2007) based on shared ideas of anti-colonialism and anti-imperialism. Like with other African nations, China has created close ties with government officials with the rhetoric of mutual benefit and aid, without interference in internal affairs.

Namibia and China's close relationship began during the years of Namibia's liberation war. China supported the South West Africa People's Organisation's (SWAPO) liberation efforts ${ }^{2}$ as part of its foreign policy in the 1970s and 1980s of supporting victims of colonialism and also raising China's profile on the international stage (Taylor; 1997: 112). The SWAPO- led government of Namibia uses the narrative of China's help during the liberation struggle (Embassy of the People's Republic of China in the Republic of Namibia; 2007) as a way to justify and further drive close relations between the People's Republic of China (PRC) and the Namibian government. This discourse is re-iterated in speeches from both governments and demonstrates a shared idea of Namibia and China being partners and allies in the fight against colonialism, apartheid and oppression. There has been an escalation of party-to-party co-operation between SWAPO party elites and the $\mathrm{CCP}^{3}$.

In parallel, the criticism of the Namibian government's relationship with China is growing. This may be due to people's concerns that some government officials could be preoccupied with strengthening bilateral relations with China for personal gain rather than pursuing relations that would help further the interests and needs of the Namibian people. The 


\begin{tabular}{c} 
AFRICAN \\
EAST-ASIAN \\
AFFAIRS \\
\hline THE CHINAMONITOR \\
\hline
\end{tabular}

very close relationship between the Chinese and Namibian government is therefore beginning to shape non-state actor views about China's engagement in the country. These perceptions are having an effect on how Namibian analysts, business people and grassroots level view China's economic presence in Namibia.

\section{China's Economic Presence in Namibia}

China's economic presence in Namibia is closely linked to its overall foreign policy goals in Africa. There are two main elements to China's economic relationship with Namibia that are shaping grassroots perceptions. These are the import of manufactured goods, often by Chinese migrant entrepreneurs, and competition in the construction industry (Dobler; 2007: 95).

The start of bilateral relations between Namibia and China in 1990 saw to the increase of Chinese businesses in Namibia. These businesses focused on small "China shops" which sold generic items (Niikondo and Coetzee; 2009: 6). "China Shops" have since become a permanent feature across Namibia, and can be found in the most remote of places. The Ministry of Trade and Industry database reflects that there are five hundred registered small Chinese shops in Namibia (Jauch and Sakaria, 2009: 11). Most Chinese shops are run and owned by private business people and many of them are not registered with the Ministry of Trade and Industry ${ }^{4}$ (Jauch and Sakaria; 2009: 11).

Chinese traders have a strategic advantage because they are familiar with the both the supply market in China (Dobler; 2009: 717) which allows them to import goods at very low prices from large wholesalers or 
factories in China (Jauch and Sakaria; 2009: 16). In the northern town of Oshikango, Chinese traders buy their supplies from bulk suppliers instead of large public wholesalers while larger quantities are ordered directly from factories in China. This eliminates the middleman and increases their profit (Dobler; 2009: 713). This way of purchasing stock means that these traders can keep their costs low and be able to undercut local businesses (Jauch and Sakaria; 2009: 16).

Chinese retail shops are seen in both a positive and negative way by local populations. Many respondents of the study (92\%) voiced that positive perceptions were due to the fact that lower-income citizens are able to afford goods that they would not be able to afford in South African or Western stores. Some respondents stated that China's retail presence has "broken the monopolies of Germany, South Africa and the United Kingdom" in the retail centre. Interviewees, however, responded negatively to the low quality of the goods. All respondents stated that the products were of inferior quality and that these goods "spoil" the market by flooding it with cheap goods. The low prices of Chinese goods have also made it very difficult for local traders to compete in the retail industry. This unfair advantage has created negative perceptions about Chinese traders in Namibia because they are seen to be taking over the retail industry and putting locals out of business.

Chinese shop owners also usually deal in cash with their local customers. This makes taxing them problematic because profit margins cannot be documented. Chinese businesses also avoid banking in Namibia so that transfers can remain unrecorded, despite the country's foreign exchange restrictions (Jauch and Sakaria; 2009: 14-15). 


\section{AFRICAN \\ EAST-ASIAN \\ AFFAIRS \\ THE CHINA MONITOR}

Eighty-seven respondents felt that this has a negative effect on the economy because the money that they make in Namibia is expected to be sent to China and does not directly contribute to the Namibian economy.

On the other hand, respondents often (74\%) credited Chinese businesses for creating unskilled employment for Namibians as shop assistants, store hands or security guards. Yet Chinese traders rely mostly on family labour and use Namibian labour for menial tasks, and respondents felt negatively about this. Many Chinese traders have noted that they do not employ people without skills because they then have to "waste" money to train them. These traders perceive Namibian locals to be untrustworthy and therefore easier to import the skills from China (Jauch and Sakaria; 2009: 15). This reinforces perceptions that Chinese traders are not benefitting the economy or helping create employment in the country.

While most visible throughout the country in trade Chinese businesses have also become a prominent feature in the construction industry ${ }^{5}$. Prominent public construction contracts ${ }^{6}$ have been awarded to these Chinese companies. The largest public project undertaken by the Chinese to date has been the State House ${ }^{7}$. This project was never put up for public tender and the Chinese government donated N\$ 55 million for its construction in 2002 "with no strings attached", as the official line is. In 2005 another undisclosed figure was granted for the State House whilst in 2006 it was announced that the Presidential home attached to the State House would be completely donated by the Chinese government, built by Chinese companies which would be tendered in China (Dobler; 2007: 101). 
This is highlighted as an example of how Chinese construction companies have been awarded prominent local government building tenders as opposed to local construction companies. There are mixed perceptions about the projects undertaken by Chinese companies. Respondents stated that they perceived these projects in a positive light because they are useful in terms of the development of infrastructure in the country. Thirty-four respondents, however, voiced negative perceptions around Chinese infrastructure engagement, suspecting China to use these projects, such as the State House, to win the favour of government officials. These projects are all constructed by Chinese companies and this has caused negative local perceptions of Chinese companies $^{8}$.

Chinese construction companies are also pursuing private sector projects, and in this, state-owned and private Chinese construction companies often submit tenders at a significantly lower price than local companies (Chen, Goldstein and Orr; 2009: 77). They can afford to do so because they purchase construction equipment and material from Chinese manufacturers at low prices (Chen, Goldstein and Orr. 2009: 82). The move into the private sector has had a large impact on local and South African construction companies as Chinese companies are able to undercut their competitors (Jauch and Sakaria; 2009: 14).

It is likely that the presence and involvement of Chinese actors will increase in the construction and the retail industry will increase. This is clearly supported by political relations between China and Namibia as the two governments seek to strengthen co-operation in various fields. 


\begin{tabular}{c} 
AFRICAN \\
EAST-ASIAN \\
AFFAIRS \\
\hline THE CHINAMONITOR
\end{tabular}

\section{China's Social Presence}

Chinese companies and small businesses have brought about a significant increase in the number of Chinese immigrants in Namibia over the past decade. It has been difficult to establish an accurate number of Chinese immigrants in Namibia as the data is not available. In 2010, a Wikileaks ${ }^{9}$ report of 2006 suggested that a default on a repayment of a loan by the Namibian government resulted in the Chinese government demanding five-thousand passports and residential documents from the department of Home Affairs (The Namibian; 2010). The Namibian government denied ever defaulting on a loan payment but were elusive about the issuing of these documents with Prime Minister Nahas Angula stating that Chinese nationals are among the lowest number of those who have acquired Namibian citizenship (Kisting; 2010). Whether or not there is any truth to these Wikileaks reports, such media coverage, in any case, is shaping perceptions.

The lack of documentation of the number of Chinese nationals in Namibia can partly be attributed to their legal status; a large number of Chinese immigrants can be expected to be there illegally. Some nationals have settled into the country on expired tourist visas hoping to not be found out by officials (Dobler; 2007: 105). The most popular option appears to be for a new migrant to pay established Chinese business people to act as immigration brokers to provide housing and employment for them when they arrive in Namibia. Immigration brokers can charge up to N\$100 000 for their services. The migrant pays this money back through working for the broker and once the debt has been repaid he or she expects to have the skills and local knowledge to start 
their own business (Dobler; 2007: 104).

Using Dobler's study of Chinese traders in the town Oshikango in northern Namibia (Dobler; 2009), inferences can be made about the Chinese community in the country. The chain migration of Chinese families which came about after Namibia and China established bilateral relations was a result of Chinese officials advertising business opportunities in Namibia in newspapers and magazines, Dobler states. Families, mostly couples move to Namibia and establish their businesses, and subsequently bring family members from China. These family members are usually single males who want to establish their own businesses later on and so come to Namibia to learn the trade in the business (Dobler; 2009: 716-717). This chain of family migration suggests that the Chinese government does not organise for these traders to come to Namibia; in fact the Chinese embassy has discouraged the establishment of small retail stores in the country (Jauch and Sakaria; 2009: 11). Chinese traders come on their own personal initiative to establish businesses and make better lives for their families. This disproves the popular view in Namibia that the Chinese government is encouraging the immigration of Chinese in the country (Jauch and Sakaria; 2009: 717).

The study also found that the Chinese migrants in Namibia cannot yet be considered as a close-knit migrant community. A key commonality is their dependence on retail trade for a living in Namibia. This, in effect, also means that there is also competition amongst them. Dobler does, however, suggest that there is a high possibility that a stable expatriate community and society of Chinese Diaspora living in Namibia will be 


\section{AFRICAN \\ EAST-ASIAN \\ AFFAIRS \\ THE CHINA MONITOR}

formed and will be shaped by the conditions exposed to them by the local population and government policies (Dobler; 2009: 724).

Perceptions shape attitudes about Chinese immigrants who are perceived to be strangers or the "other" and this has fuelled feelings of xenophobia. Sixty-eight respondents expressed that Chinese nationals' physical presence in Namibia is seen as threatening to the local population. One respondent stated that there were "too many of them in the country" and that they were "taking up space" in terms of housing and schools. These feelings of xenophobia are further fuelled by the lack of interaction between Chinese citizens and the local population. Chinese families rarely have contact with other nationals outside of a business or retail environment. The language barrier between Chinese nationals and Namibians also seems to contribute to feelings of xenophobia.

\section{Socio-Economic Effects of China in Namibia}

Namibia's current practice in attracting investment from and trade with China has had the effect of compromising the country's labour laws. Local construction companies and trade unions blame the government for not forcing Chinese construction companies to comply with Namibian labour laws. Chinese companies tend to be the lowest-paying employers in Africa compared with other employers in the same sector (Jauch; 2011: 52), and the situation is no different in Namibia.

A study conducted by the Labour Research and Resource Institute on labour practices in Namibia in 2009 found that many Chinese companies do not pay the N\$ 8.44 per hour minimum wage agreed upon by the construction industry. Chinese employers consider Namibian workers as 
efficient as Chinese workers (Jauch and Sakaria; 2009: 23). Low productivity means that they do not deserve the minimum wage and so Chinese employers reserve the right to choose how much to pay them (Jauch; 2011: 52) ${ }^{10}$. These sentiments suggest that Chinese employers do not comply with Namibia's labour laws. Respondents felt that the Chinese exploit the local labour force by not complying with the labour laws.

An example of a reaction to low wages and poor working conditions is the strike action by MANWU members in March 2011. Construction workers employed by Chinese-owned New Era Investment downed tools in an attempt to force the company to comply with their demands for better terms and conditions of employment (Smit; 2011). Strike action was a result of the large number of Chinese workers displacing local construction workers and the exploitation of Namibian workers by Chinese construction companies ${ }^{11}$. MANWU members pointed out that they were not being supported by the government and called for action against contractors who bribe government officials (Smit; 2011) ${ }^{12}$. The strike action of New Era Investment workers shows that if Namibian trade unions and workers had more support from government and had more bargaining power it could lead to Chinese companies adhering to the country's labour laws. Respondents expressed that the government has not tried to adequately deal with the contravention of labour laws by Chinese companies and this is creating negative perceptions and raising doubts about the integrity of the Namibian government.

The Construction Industry Federation (CIF) has on numerous occasions expressed their concern about Chinese firms profiting from preferential 


\section{AFRICAN \\ EAST-ASIAN \\ AFFAIRS \\ THE CHINA MONITOR}

treatment in the allocation of tenders (Dobler; 2007: 101). The local construction companies that are organised under the CIF are subjected to regulations such as providing proof of registration as a Namibian tax payer, certificates of good standing from the Social Security Commission, and valid affirmative action certificates from the Employment Equity Commission (Odada and Kakujaha-Matundu; 2008: 23) These local companies complain that Chinese businesses do not have to comply with these regulations (Odada and Kakujaha-Matundu; 2008: 23), thereby giving them an unfair advantage. The bids of Chinese companies on public contracts are so low that local companies struggle to compete with them (Bloom and Poplak; 2011). In 2007, Murray \& Roberts and Namibia Construction took the Namibian tender board to the high court. The two construction companies requested the high court to stop China Nanjing International from starting work on the head offices of the Ministry of Lands and Resettlement in Windhoek after China Nanjing International was awarded the N\$ 74.4 million tender. Murray \& Roberts and Namibia Construction wanted the high court to declare the tender null and void on the basis that it was not in compliance with the Affirmative Action Act and Labour Acts (Heita; 2007). The Chinese company was also accused of not being a member of the CIF nor the Employment Equity Commission, both a pre-requisite for the tender process. Work on the head offices began and construction was almost halfway complete whilst the lawsuit returned to the high court for the third time in 2009 (Menges; 2009). This lawsuit is an example of the frustrations facing local construction companies in Namibia who feel as though Chinese companies have no respect for the laws of the country and have the support of the government to do so. 
Despite the negative effects of Chinese competition in the construction industry, there has been a positive effect. Productivity and efficiency have improved and construction costs have decreased (Dobler; 2007: 101). Respondents expressed positive perceptions about China in terms of their role in aiding development by building infrastructure. Sixty-two respondents also stated that Namibians could benefit from learning skills and work ethic from Chinese labourers. One respondent stated that he preferred hiring Chinese construction companies because they were "fast and cheap". Another respondent stated that there was "a degree of expertise" in their buildings and "efficiency in their work".

Overall, however, the increasing number of Chinese businesses in Namibia has become of concern in Namibia and is predominantly creating negative perceptions at grassroots levels and local traders. The five hundred Chinese shops and businesses registered with the Ministry of Trade and Industry is unlikely to be a true reflection of the situation. The majority of small Chinese businesses do not register themselves with the Ministry of Trade and Industry. Many of these small business traders arrive in the country as employees with large state owned enterprises and then take advantage of openings in the market. They resign from their employment and start their own businesses. They then invite relatives and friends to help them once their businesses begin to grow (Thorniley; 2010). This makes it difficult to keep accurate figures of how many Chinese businesses are operating in Namibia. Majority of the respondents expressed that they were very much aware of the increasing number of Chinese businesses and this is likely to become more of a political issue in the country. 


\section{AFRICAN \\ EAST-ASIAN \\ AFFAIRS \\ THE CHINA MONITOR}

Local businesses are concerned about their livelihoods as the increase in Chinese owned stores is increasing fierce competition. In 2008, northern indigenous business people appealed to government to protect them from foreign owned businesses that have successfully set up businesses as a result of the free-market system policy introduced in 1990. Even though they are not completely opposed to foreign business and acknowledging some positive effects on the economy, they feel that these businesses should be restricted to areas that Namibians are not involved in. Singling out Chinese and Indian owned stores, they expressed that it is unfair to compete with people who are financially backed by bigger companies in their countries (Shivute; 2008).

In Oshakati, clothing vendors and small garment manufacturers are against what they call a "Chinese invasion and colonisation" and a "competitive threat" (Xoagub; 2011). Local businesses and respondents of the study further complained about the local merchandise being sold by the Chinese. Such an example is the manufacturing and importing of cheap materials from China used in making the traditional Owambo attire, Ondelela. The low prices of these items displace local manufacturers as it is very difficult to compete with Chinese traders who are active in the lower cost segments.

The labour issue also extends to the retail sector. Local workers employed by Chinese businesses often do not have employment contracts or any type of job security (Jauch and Sakaria; 2009: 22). The LARRI study found that in both the construction and retail sector, local workers have complained of verbal abuse, intimidation and harassment by their Chinese employers. The workers felt that that had no rights to 
express their views or lodge any complaints out of fear that they would be retrenched (Jauch and Sakaria; 2009: 24). Employers indicated that they had to work between 7:30 - 17:30 on week days and 7:30-13:00 on Saturdays and Sundays; these hours are longer than permitted by Namibian labour laws. Workers are also expected to work during public holidays without extra pay and did not receive lunch breaks, which is also in violation of labour laws (Jauch and Sakaria; 2009: 25). The Namibian government has yet to take any decisive action against Chinese businesses that do not comply with the country's labour laws (Shejavali; 2009). This is having the effect of compromising the integrity of the government. The current debate about China's political, economic and social presence demonstrates that various sectors of society are taking notice of Sino-Namibian relations in terms of what Namibians perceive as national interests.

Seventy-one of the respondents expressed frustration that grassroots perceptions of the Chinese in Namibia are not taken seriously and suspect this to be an effect of the SWAPO party's close relationship with the Chinese government. The SWAPO party may become more mindful of negative public perceptions of Sino-Namibian relations as this could ultimately have the effect of costing it votes in future elections. It is likely that growing resentment will, over time, affect the government's behaviour towards privileging Chinese state owned companies and perhaps force it to become more vigilant in making sure these companies comply with the country's laws and regulations. 


\begin{tabular}{c} 
AFRICAN \\
EAST-ASIAN \\
AFFAIRS \\
\hline THECHINAMONITOR
\end{tabular}

\section{The Political Ramifications of China's Presence}

Before addressing the political ramifications of China's presence in Namibia, it is important to note the nature of its political system. Namibia's political system is dominated by the SWAPO party. Since independence in 1990, SWAPO has managed to obtain and maintain political control in Namibia. This is largely due to the fact that party followers share the same view that SWAPO was the leading liberator of Namibia in its struggle for independence.

Table 6: Percentages (\%) of SWAPO votes from 1989 to 2009

\begin{tabular}{|l|c|c|c|c|c|}
\hline Year & $\mathbf{1 9 8 9}$ & $\mathbf{1 9 9 4}$ & $\mathbf{1 9 9 9}$ & $\mathbf{2 0 0 4}$ & $\mathbf{2 0 0 9}$ \\
\hline Percentage & 57.3 & 73.89 & 76.15 & 75.1 & 75.27 \\
\hline
\end{tabular}

Source: Elections in Namibia, African Elections Database. Available online at: http://africanelections.tripod.com/na.html

The Namibian political system displays characteristics of a one-party state under increasing autocratic rule (Melber, 2005: 146) where opposition parties are unable to gain enough votes to seriously challenge SWAPO dominance (Melber; 2008: 66). SWAPO's reputation and identity as being the liberator of Namibia and the absence of a strong alternative opposition parties remains an issue in the political system because it limits the ability of non-SWAPO party actors to effectively play a role in the countries decision making process.

Official government statements of China being an ally against colonialism are an indication of how the Namibian government views and justifies China's presence in Namibia. It is this intersubjective 
understanding that is causing concern amongst local business people and grassroots levels of society.

The nature of China's foreign policy of mixing aid and business in government agreements were viewed negatively by the respondents of this study. Most Chinese agreements require that financial aid and loan contracts be awarded to Chinese contractors that have been selected by the Beijing government. That means that information such as project costs, loan terms and repayment conditions is not provided (LaFraniere and Grobler; 2009). A case which resulted in the Namibian government taking a Chinese state-owned company, Nuchtech, to court in 2008, may serve as an illustration. The $\mathrm{N} \$ 55.3$ million dollar tender deal for cargo scanners revealed that N\$ 4.2 million dollars in the form of 'kickbacks' was sent to a front company set up by two Namibian officials and a Chinese Nuchtech representative (LaFraniere and Grobler; 2009). Such problems could be reduced if Namibia insisted on independently comparing prices before accepting the tender terms as is. The state's perception that China is a good friend and that the government will receive good value for its money apparently reduces vigilance when it comes to signing agreements (LaFraniere and Grobler; 2009).

Government officials have been steadfast in denouncing any criticism of China's relationship with Namibia, stating that negative reports in the local media are being perpetuated by the West to cause suspicion and distrust among the local population about China's interests in Namibia (Jauch and Sakaria; 2009: 6). Former Minister of Trade and Industry, Immanuel Ngatjizeko lashed out at criticism saying that the "unproductive sentiments bordering on xenophobia and outright 


\section{AFRICAN \\ EAST-ASIAN \\ AFFAIRS \\ THE CHINA MONITOR}

narrow-mindedness not supported by historical and empirical evidence should not be entertained by Africans as regards to our Chinese brothers and sisters, who supported us all these years without any counter-demands" (Katswara; 2007). Former Secretary General of SWAPO Dr. Ngarikutuke Tjiriange also noted that China helped Namibia through its liberation struggle, unlike the US and Britain, thus proving that it was a true ally and friend to Namibia (Jauch and Sakaria; 2009: 5).

SWAPO Youth League President Elijah Ngurare also expressed that negative perceptions are unavoidable but believes that criticism of China is being driven by the West (Personal Communication, 10 March 2011). Ngatjizeko affirmed that the Namibian government had no doubt that China meant well in Africa and was entitled to trade and invest in any country of its choice. He argued that negative sentiments were aimed at causing suspicion and distrust among Africans (Katswara 2007). A speech from President Pohamba suggested that China had more of a right to operate in Namibia than other Western countries due to its historical ties. In March 2011, Pohamba defended Chinese business people operating in Namibia by expressing his disappointment of black Namibian businesses for condemning them. He demanded to know why they do not criticise the presence of South African business people who were in the past responsible for oppressing Namibians before independence. Pohamba further expressed that it was shameful for black Namibian business people to condemn the Chinese because they had provided Namibia with arms during the liberation struggle (The Namibian; 2011). 
In response, Pohamba came under heavy attack by various political and economic groups in Namibia. Most notably, the Namibia Chamber of Commerce Institute (NCCI) Chief Executive Officer, Taara Shaanika criticised the president for misunderstanding the concerns of Namibian business people. Shaanika argued that the local condemnation of Chinese business in Namibia stemmed from concerns about respect for the country's laws and policies. He therefore called for Pohamba to "undertake serious engagement with the private sector to design and formulate clear policies on how countries such as China should do business with Namibia at a local level that is beneficial to the local economy" (Heita; 2011). Illegal and unethical business practices, non-payment of taxes, dealing in foreign currency, the disrespect for labour laws, illegal siphoning of funds outside the country and the engagement in micro businesses through purported direct investments, according to Shaanika, are the main problems with Chinese and other foreign businesses in Namibia (Heita; 2011).

Shaanika, argues that China's help during the war of independence should not be an "open door for any nation to side step [Namibia's] laws and national priorities" and that Namibia's "friendship with others should not disadvantage [its] citizens" (Heita; 2011). It is debatable as to how much help Namibia received from China during the liberation war. Evidence suggests that the Soviet Union provided most of SWAPO's military weapons and training. NamRights, a human rights monitoring and advocacy organisation also argues that "white imperialist" Sweden...accorded SWAPO much more support in terms of logistics, money and vital assistance than China" (NamRights; 2011). 


\begin{tabular}{c} 
AFRICAN \\
EAST-ASIAN \\
AFFAIRS \\
\hline THE CHINAMONITOR \\
\hline
\end{tabular}

Official Sino-Namibian relations appear to make citizens question the integrity of the state and of the governing elite against a context of the ruling party's dominance. Government perceptions and the nature of Namibia's political system allows for little room for non-state actor views to effectively impact on foreign policy in Namibia. Local citizens do, however, reserve the power to hold the state accountable for its lack of integrity when it comes to official Sino-Namibian relations. Non-state actor perceptions about the Chinese are predominantly based on China's economic engagement with the country and from its relationship with the SWAPO-dominated government. More specifically, China's increased presence in the construction and retail industries as a result of this relationship is playing a large role in forming local perceptions of Sino-Namibia relations.

\section{Conclusion}

China's seemingly aggressive economic presence in the construction and retail industry is mostly responsible for shaping negative perceptions of Sino-Namibian relations. Citizens are very much aware of the use of Chinese companies and workers in the construction of public and private projects and the increase in the number of Chinese traders in the country. The apparent disinterest of the government in taking action against China's dominant economic and social presence in the country is causing widespread criticism of Sino-Namibian relations. Despite the positive perceptions that lower-income citizens have for small Chinese retailers and their affordable goods, they pale in comparison to the overall negative perceptions of Chinese presence in Namibia.

Both governments use the narrative of a shared colonial past and "invoke 
history to suggest a bond that is a result of a genuine kinship rather than mutual capacity" (Bloom and Poplak; 2011). There are public perceptions that China is using this relationship to gain access to Namibia's resources, be awarded tenders for public projects and bypass the country's laws. Chinese companies appear to be receiving preferential treatment from the government at the expense of local companies.

Government statements that China is a "friendly big power" (Kisting; 2010) that helped Namibia during the struggle for independence is problematic. The government's rhetoric that China militarily and diplomatically supported Namibia during the liberation struggle cannot be an excuse for it to not have to comply with Namibia's laws or disadvantage the local population. Vekuii Rukoro ${ }^{13}$ argues that Namibia should not be naive when dealing with its "former benefactors during the liberations struggle" (Duddy; 2009). He argues that it is naive to believe that China is not pursuing its own narrow national interests at the cost of Namibia's national interests (Duddy; 2009). The state has tried to justify China's presence in the country arguing that the benefits of Sino-Namibian relations outweigh the negative. In August 2010, Hage Geingob expressed his dissatisfaction of anti-Chinese rhetoric in Namibia and argued that the Chinese are not in Namibia to take away employment from locals (Kisting; 2010).

Civil society as a concept is still regarded as suspicious and foreign controlled (Tonchi; 2002: 4). It therefore seems unlikely that negative perceptions from the public will translate into a change of policy towards Sino-Namibian relations. However, increased criticism is likely have the 


\section{AFRICAN \\ EAST-ASIAN \\ AFFAIRS \\ THE CHINA MONITOR}

effect of changing how the government engages with China. Statements from various government officials suggest that the state is becoming aware of the problems with the present nature of Sino-Namibian relations. Deputy Minister of Foreign Affairs Peya Mushelenga, stated that the grassroots criticism of China's economic presence in Namibia is legitimate. There is government awareness that Chinese businesses are making it difficult for Namibians to compete in the local market and that investors are importing unskilled labour that can be done by Namibians (Personal Communication, 10 May 2011). Negative perceptions of China's presence in Namibia suggests that people want the government to protect certain sectors, specifically the retail and construction industries, as a way of coping with the influx of Chinese business in the country. Grassroots levels have the ability to hold the government accountable for the way it handles Sino-Namibian relations. This would allow for the government to show that it has the integrity to deal with the Chinese presence in Namibia. Non-state actor perceptions can therefore, over time, drive changes in domestic politics and Namibia's foreign relations with China.

With the number of Chinese migrants rising, it may be beneficial for the government to strategically take advantage of these Chinese migrants to benefit its own interests by creating opportunities that can lead to development. Tweya suggests that Namibia should take advantage of Sino-Namibia relations by borrowing certain aspects of China's development model, culture of hard work and its ability to focus on economic goals (Personal Communication, 3 March 2011). 
Growing negative perceptions could possibly have the effect of undermining the advantages of Namibia's relationship with China. Growing criticism of China could prove to be detrimental for the government and in turn for official Namibia-China relations. It is therefore crucial that the government make an effort to address these negative perceptions at grassroots level before they manifest themselves in violence against Chinese immigrants or possible wider social unrest.

\section{End Notes}

${ }^{1}$ The 100 respondents, aged 18 years and older, were chosen at random and were assured of their anonymity.

${ }^{2}$ Namibia's Liberation Struggle was fought between 1966 and 1990.

${ }^{3}$ In June 2003, the Communist Party of China (CPC) donated US\$ 30000 to SWAPO. This money was used to print SWAPO material for the extraordinary congress set which was held in 2004 . When this donation was criticised by opposition parties, SWAPO party defended itself by stating that foreign funding of political parties was not illegal in Namibia (Sherbourne; 2005: 6).

${ }^{4}$ Many shop owners set up their own businesses once they obtain a work permit (Jauch and Sakaria; 2009: 11)

${ }^{5}$ The five main Chinese companies that have set up in Namibia are China State Construction, China Nanjing International, New Era Investment, China Zhengtai and China Jiangxe (Odada and Kakujaha-Matunda, 2008: 23)

${ }^{6}$ These include the Windhoek Supreme Court (1994-1997), the police station, prison and police training college (1996-1997) and the Magistrates Court in Katutura (1997-1999), one hundred and two houses in Katima Mulilio (1999) and a new New Town Council building in Helao Nifidi Town (2006) (Dobler; 2007: 100). 


\section{AFRICAN \\ EAST-ASIAN \\ AFFAIRS \\ THE CHINA MONITOR}

${ }^{7}$ The State House is the President's residence.

${ }^{8}$ Ninety-one respondents expressed that they were unhappy about the number of projects being constructed by Chinese businesses.

${ }^{9}$ US Ambassador Josiah Rosenblatt was informed about the alleged fivethousand Chinese families' resettled in Namibia as a result of the Namibian government defaulting on a loan, by French lawyer Allain Feneon. Former Togo President Koba was also at the meeting (The Namibian; 2010).

${ }^{10}$ Chinese employers claim that they have an agreement with the Metal and Allied Namibian Workers Union (MANWU) to only pay workers that reach a specific target each day. Chinese companies argue that local general workers do not apply for the minimum wage because they do not reach these targets. MANWU has claimed that no agreement exists (Jauch and Sakaria; 2009: 24).

${ }^{11}$ New Era Investments was also accused of paying below minimum wage, mistreating workers, not deducting union membership dues from wages and "not adding value to the Namibian economy and lives of the workers" (Smit; 2011).

${ }^{12}$ A day after the strike, New Era Investment gave into workers demands and agreed to pay minimum wage and register its employees with the Social Security Commission and the Namibia Building Workers Pension Fund. The agreement, however, only covered three out of the ten demands of MANWU and issues such as housing allowance, medical aid and union membership deductions were not addressed (Smit; 2011).

${ }^{13}$ The Chief Executive Officer of First National Bank Group of Namibia

\section{References:}

Bloom, K. and Poplak, R. 2011. “'Chinese invasion': old foes police a new 
frontier" Times Live, 26 March 2011. Accessed 20 July 2011. Available online: http://www.timeslive.co.za/lifestyle/2011/03/26/chinese-invasion-old-foespolice-a-new-frontier

Chamber of Mines of Namibia, 2010. Annual Review. Accessed on 19 October 2011. Available online: http://www.chamberofmines.org.na/uploads/media/ Chamber_of_Mines_AR_2010.pdf

Chen, C., Goldstein, A. and Orr, R.J. 2009. "Local Operations of Chinese Construction Firms in Africa: An Empirical Survey" The International Journal of Construction Management, pp. 75-76

Deutsche Gesellschaft für Internationale Zusammenarbeit 2010, GIZ in Namibia German Development Service. Accessed on 6 September 2011. Available online: http://www.namibia.ded.de/en/giz-in-namibia.html

Dobler, G. 2007. "Old ties or new shackles? China in Namibia" in Melber, H. (ed.), Transitions in Namibia: Which Changes for Whom? Stockholm: Elanders Gotab

Dobler, G. 2009. "Chinese Shops and the Formation of a Chinese Expatriate Community in Namibia” The China Quarterly, 199, pp. 707-727

Duddy, J. 2009. "Namibia warned against 'soft loans"”, The Namibian, 25 August 2009. Accessed on 6 September 2011. Available online: http:// www.namibian.com.na/index.php?id=28\&tx ttnews[tt_news] $=58848 \&$ no $\_$cache $=1$

Embassy of the People's Republic of China in the Republic of Namibia. 2007. Interpretation of China-Namibia Relations: Chinese Ambassador's view. Accessed 13 April 2011. Available online at: http:// www.na.chineseembassy.org/ eng/zngx/t410246.htm

Heita, D. 2007. "Tender Board faces lawsuit in Chinese saga" The Economist, 


\section{AFRICAN \\ EAST-ASIAN \\ AFFAIRS}

THE CHINA MONITOR

30 November 2007. Accessed on 6 September 2011. Available online: http:// www.namibian.com.na/index.php?id=28\&tx_ttnews[tt_news]

$=30934 \&$ no cache $=1$

Heita, D. 2011. "NCCI disagrees with President on Chinese" New Era, 22

March 2011. Accessed on 22 March 2011. Available online: http://

www.newera.com.na/article.php?articleid $=37923 \&$ title $=$ NCCI $\% 20$ disagrees $\%$

20with $\% 20$ President $\% 20$ on $\% 20$ Chinese

Jauch, H and Sakaria, I. 2009. "Chinese Investments in Namibia: A Labour Perspective”. Windhoek: Labour Resource and Research Institute (LARRI).

Jauch, H. 2011. "Chinese Investments in Africa: Twenty-first Century Colonialism?” New Labour Forum 20 (2), pp. 49-55

Katswara, T. 2007. "China means well in Africa: Ngatjizeko", The Namibian, 3 April 2007. Accessed on 14 June 2010. Available online: http:// www.namibian.com.na/index.php?id=28\&tx ttnews[tt news] $=30934 \&$ no cache $=1$

Kisting, D. 2010. "Namibia's trade with China up by 600\%", The Namibian, 13 August 2010. Accessed on 8 December 2010. Available online at: http:// www.namibian.com.na/index.php?id=28\&tx ttnews[tt news] $=71353 \&$ no $\quad$ cache $=1$

Kisting, D. 2010. "Govt elusive on settler deal", The Namibian, 16 December 2010. Accessed 18 March 2011. Available online: http:// www.namibian.com.na/index.php?id=28\&tx_ttnews[tt_news] $=76023 \&$ no cache $=1$

LaFraniere, S. and Grobler, J. 2009. "China spreads Aid in Africa, with a catch”, The New York Times, 22 September 2009 (Accessed 10 February 2010) Available online at: http://www.nytimes.com/2009/09/22/world/ 


\section{africa/22namibia.htm?sq=John\%Grobler\&st=cse\&scp}

Melber, H. 2005. "People, Party and Parliament: Government and Governance in Namibia" in Mohamed Salih, M.A. (ed.), African Parliaments: Between Governance and Government. New York: Palgrave Macmillian

Melber, H. 2008. "SWAPO is the Nation, and the Nation is SWAPO": Government and Opposition in a Dominant Party State, The Case of Namibia in Melber, H. (ed.), Political Opposition in African Countries: The Cases of Kenya, Namibia, Zambia and Zimbabwe. Uppsala: Sweden

Menges, W. 2009. "Attack on lands office building contract stuck in starting blocks" The Namibian, 29 January 2009. Accessed on 6 September 2011. Available online: http://www.namibian.com.na/index.php?id=28\&tx ttnews\% $\underline{5 \mathrm{Btt} \text { news } \% 5 \mathrm{D}=2560 \& \text { no } \text { cache }=1}$

Ministry of Foreign Affairs of the People's Republic of China. 2007. "Hu Jintao Meets with Head of South West African People's Organization (SWAPO) and Founding President of Namibia Nujoma" 6 February 2007. Accessed on 23 July 2011. Available online: http://www.mfa.gov.cn/eng/wjb/zzjg/fzs/ gjlb/3049/3051/t296101.htm

Mongudhi, T. 2009. "You cannot bribe with a bursary' - Mbumba" The Namibian, 3 November 2009. Accessed on 15 June 2011. Available online: http:// www.namibian.com.na/index.php?id=28\&tx ttnews[tt news] $=$ 61365\&no_cache $=1$

"Namibia needs strategy on Chinese influx" The Namibian, 20 June 2011. Accessed on 20 June 2011. Available online: http://www.namibian.com.na/ index.php?id $=28 \&$ tx ttnews $[$ tt news $]=83155 \&$ no cache $=1$

NamRights. 2011. "Pohamba Chinese gaffe Exposes Him" 17 March 2011. Accessed on 22 March 2011. Available online: http://www.nshr.org.na/index.php? 


\section{AFRICAN \\ EAST-ASIAN \\ AFFAIRS}

THE CHINA MONITOR

\section{$\underline{\text { module }}=$ News $\&$ func $=$ display $\&$ sid $=1567$}

Niikondo, A., \& Coetzee, J. 2009. Perceptions on the impact of Chinese businesses in Namibia: A case study of the retail and construction sector in Windhoek. Windhoek: Friedrich-Ebert-Stiftung.

Ntinda, A. 2010. "Zoom in Wikilieaks allegations" SWAPO Party. Accessed on 23 July 2011. Available online:

http://

\section{www.swapoparty.org/zoom in 31.html}

Odada, J.E. and Kakujaha-Matundu, O. 2008. "China-Africa Economic Relations: The Case of Namibia". Department of Economics, University of Namibia. Prepared for the African Economic Research Consortium, pp. 1-36

Personal Communication with Deputy Minister of Trade and Industry Tjikero Tweya, on 3 March 2011 in Windhoek

Personal Communication with SWAPO Youth League President Elijah Ngurare, on 10 March 2011 in Windhoek

Personal Communication with RDP Secretary General Jesaya Nyamu, on 25 March 2011 in Windhoek

Personal Communication with Deputy Minister of Foreign Affairs Peya Mushelenga, on 10 May 2011 in Windhoek

"Picking on Chinese: 'Shame on you,' says Pohamba." The Namibian, 17

March 2011. Accessed on 18 March 2011. Available online: http://

www.namibian.com.na/index.php?id=28\&tx ttnews[tt_news] $=79284 \&$ no cache $=1$

Shanghai Daily. 2011. "Hanlong keen to acquire Bannerman” 12 July 2011. Accessed 25 July 2011. Available online: http://www.chinamining.org/ Investment/2011-07-12/1310439437d47580.html 
Sherbourne, R. 2005. "Comrades and Capitalists: The growing presence of China in the Namibian Economy and its possible economic and political implications" Windhoek: Friedrich-Ebert-Stiftung

Shindondola-Mote, H. 2009. Uranium Mining in Namibia: The mystery behind 'low level radiation'. Labour Resource and Research Institute, Windhoek. Accessed on 29 June 2011. Available online: http://www.tegenstroom.nl/sites/ default/files/files/UmininginNamib.pdf

Shivute, O. 2008. "Northern businesses call for protection against foreign rivals" The Namibia, 3 July 2008. Accessed on 6 September 2011. Available online: http://www.namibian.com.na/index.php?id=28\&tx_ttnews[tt_news] $=46136 \&$ no cache $=1$

Shejavali, N. 2009.“Chinese labour practices reflect 'blind-faith' FDI strategy" The Namibian, 27 March 2009. Accessed on 14 June 2010. Available online: http://www.namibian.com.na/index.php?id=28\&tx_ttnews[tt_news] $=53784 \&$ no_cache $=1$

Smit, N. 2007. "Chinese firm bows to pressure" The Namibian, 30 March 2011. Accessed on 30 March 2011. Available online: http://www.namibian.com.na/ index.php?id=28\&tx ttnews[tt news] $=79809 \&$ no cache $=1$

Smit, N. 2011. "Construction workers stand up to Chinese firm" The Namibian, 29 March 2011. Accessed 30 March 2011. Availaible online: http:// www.namibian.com.na/index.php?id=28\&tx ttnews[tt_news] $=79744 \&$ no cache $=1$

Smit, N. 2011. "Builders fed up with Chinese firms" The Namibian, 9 February 2011. Accessed on 30 March 2011. Available online: http:// www.namibian.com.na/index.php?id=28\&tx_ttnews[tt_news] $=77744 \&$ no cache $=1$ 


\section{AFRICAN \\ EAST-ASIAN AFFAIRS}

THE CHINA MONITOR

Taylor, I. 1997. "China and SWAPO: The role of the People's Republic of China in Namibia's liberations struggle and post-independence relations" South African Journal of International Affairs Vol. 5, No. 1, pp. 110-122

Tonchi, V. L. 2002. "Civil Society and Democracy in Namibia" Development Policy Management Forum Policy Brief Series, No. 6

Thorniley, T. 2010. "Chinese entrepreneurs 'invade'Africa” Uhuru, 7 August 2010. Accessed on 30 March 2011. Available online: http:// iuhuru.com/2010/08/chinese-entrepreneurs-invade-africa/

Weidlich, B. 2006. "40 000 Chinese in Namibia, MP says 'Scramble for Africa on again', 21 November 2006. Accessed 14 June 2010. Available online: http:// www.namibian.com.na/index.php?id=28\&tx ttnews[tt_news] $=28224 \&$ no cache $=1$

Weidlich, B. 2009. "China gives N\$ 65 million grant" The Namibian, 10 February 2009. Accesed on 14 June 2010. Available online at: http:// www.namibian.com.na/news-articles/national/full-story/archive/2009/february/ article/china-gives-n65-million-grant/ 